\title{
AMELIORATIVE EFFECT OF LIPOXIN A4 ON TESTICULAR DAMAGE INDUCED BY HIND LIMB ISCHEMIA/REPERFUSION INJURY IN RATS: ROLE OF HMGB-1
}

\author{
Abeer A. Abo Zeid ${ }^{1}$ and Noha M Shafik ${ }^{2}$
}

\author{
Physiology Department ${ }^{1}$, \\ Biochemistry Department ${ }^{2}$ \\ Faculty of Medicine, Tanta \\ University - Egypt \\ Corresponding author: \\ Dr. Abeer Abed Abo Zeid \\ Mobile: 01002085005 \\ E mail: \\ abeer.abozeid 2@yahoo.com \\ Received: 13/3/2019 \\ Accepted: 1/4/2019
}

\begin{abstract}
:
Background: Hind limb ischemia/reperfusion injury (I/R) inducing testicular damage is a medical urgency that requires urgent intervention.

Aim of the work: to investigate involvement of $H M G B 1$ and the effect of Lipoxin-A 4 (LX A4) on remote testicular injury caused by hind limb $(I / R)$.

Methods: 45 adult male Wister rats were divided into 3 equal groups; sham-operated group, untreated hind limb $(I / R)$ group and LXA4 pretreated hind limb (I/R) group. Malondialdehyde (MDA), catalase activity, nitrite/ nitrate, tumor necrosis factor-alpha (TNF$\alpha)$, caspase-3 activity and high mobility group box-1 protein (HMGB-1) concentration and its relative mRNA expression were measured in testicular tissue. Serum level of free testosterone was also measured. Histopathological examination of testicular tissue was done as well as caspase-3 activity.
\end{abstract}

Results: The untreated hind limb (I/R) injury group showed significant increase in testicular MDA, nitritel nitrate, $T N F-\alpha$, caspase-3, as well as relative $m R N A$ expression and concentration of $H M G B-1$, with significant reduction of testicular catalase activity and serum free testosterone. These biochemical results were significantly reversed in LXA4 pretreated hind limb (I/R) group. In addition there was significant negative correlation between serum free testosterone level and either HMGB1 concentration and its relative $m R N A$ expression, testicular MDA, nitrite/nitrate, TNF- $\alpha$ and caspase-3 activity and significant positive correlation with catalase activity. These results were corroborated by immunehistochemistry of caspase-3 and histopathological results of testicular tissue.

Conclusion: $H M G B 1$ has a role in pathophysiology in $I / R$ remote injury of testis and LXA4may play an important ameliorative effect on it due to antioxidant, anti-inflammatory, antiapoptotic effects and its ability to increase NO production

Keywords: Lipoxin A4, HMGB protein 1, hind limb ischemial reperfusion, testis.

\footnotetext{
Abbreviations

(LX A4) Lipoxin A 4, ischemia/reperfusion injury (I/R), malondialdehyde (MDA), tumor necrosis factor-alpha (TNF- $\alpha$ ), high mobility group box-1 protein (HMGB-1, reactive oxygen species (ROS), NF- $\mathrm{kB}$ (nuclear factor kappa-light-chain-enhancer of activated B cells), NO (nitric oxide), inducible nitric oxide synthase (iNOS), toll-like receptors 4 (TLR-4), peroxisome proliferator-activated receptor- $\gamma(\mathrm{PPAR} \gamma)$, nuclear factor E2-related factor 2 (Nrf2), endothelial nitric oxide synthase (eNOS), interleukin $-1 \alpha(\mathrm{IL}-1 \alpha)$,
} 
interleukin -10(IL-10), interleukin -6 ( IL-6), receptor for advanced glycation end products (RAGE), lipopolysaccharide (LPS) .

\section{INTRODUCTION:}

Hind $\operatorname{limb}(\mathrm{I} / \mathrm{R})$ is a medical urgency may occur clinically after severe crush wounds, vascular injury, in obese diabetics who have compromised lower extremity perfusion or some orthopedically surgical techniques ${ }^{(1)}$. Tissue damage in the ischemic phase is due to energy deficiency and disturbance of cellular homeostasis, while the reperfusion phase induces inflammatory reactions implicating reactive oxygen species (ROS) with endothelial cells damage, leukocytic infiltration and apoptosis that may exacerbate local injury ${ }^{(2)}$. Skeletal muscle $(\mathrm{I} / \mathrm{R})$ is accompanied with systemic inflammatory reactions that have harmful effect on remote organs (liver, lung, kidney, heart and testis) ${ }^{(3)}$, however, the mechanism by which the local tissue damage induces distant organ failure is still unclear. HMGB1 is a nuclear protein named for its high mobility that has intra-nuclear functions where it is concerned with nucleosome stabilization, control of genetic transcription and reconstruction and restoration of DNA. In addition, its extracellular function has been discovered where it acts as a pro inflammatory cytokine involved in the pathogenesis of different conditions including inflammatory and autoimmune diseases $^{(4)}$. During hind limb $I / R$ the damaged muscular cells as well as the inflamed vascular tissue massively release HMGB1 that may acts as a signaling molecule that is involved in pathophysiology of $I / R^{(5)}$. Lipoxin A4 (LXA4) is an endogenous arachidonic acid derivative that is catalyzed by 15-lipoxygenase enzyme. LXA4 has potent anti-inflammatory effects by inhibition of neutrophil infiltration and activation, reducing the reactions of different cells to pathogenic stimuli and pro inflammatory cytokines and inhibits the release of pro inflammatory cytokines ${ }^{(6)}$. In addition, it inhibits the release of toxic complexes as ROS and it has been documented that LXA4 could protect organs against apoptosis ${ }^{(7)}$. However available data about the effects of LX A4 on remote testicular injury caused by hind limb (I/R) and its effect on HMGB-1 as pro inflammatory mediator are limited.

\section{AIM OF THE WORK:}

So, the purpose of the present study was to study role of HMGB-1inpathophysiology of hind limb (I/R), and to explore the role of LXA4 on testicular injury caused by hind $\operatorname{limb}(\mathrm{I} / \mathrm{R})$ and its effect on HMGB-1.

\section{MATERIALS AND METHODS:}

Animals: The present work was carried out on 45 males adult Wistar rats of local strain from animal house of Faculty of Science, Tanta University weighing 200-250 $\mathrm{gm}$. Rats were housed in isolated cages in temperature-controlled animal room, on 12hour light/ dark cycle with free access to water and standard chow $[24 \%$ (\% kcal) protein, $58 \% \mathrm{CHO}, 18 \%$ fat $]^{(8)}$

These animals were divided into 3 equal groups, each of 15 rats. All experiments were conducted in accordance with the Guide for the Care and Use of Laboratory Animals ${ }^{(9)}$, and the experimental protocol was approved by ethical committee of Tanta University, Faculty of Medicine (2018).

Chemicals: All chemicals used unless otherwise noted were purchased from Sigma (St. Louis, MO, USA). Chemicals and solvents were of high analytical grade. Lipoxin A4 was obtained from Egyptian company of Biotech Industries (ECBI).

\section{Experimental design:}

Ischemia reperfusion injury model for hind limb:

Under aseptic conditions, rats were anaesthetized with I.P. injection of 
pentobarbital $(50 \mathrm{mg} / \mathrm{kg}$ body weight). The lower limb ischemia-reperfusion method was done according to previous method reported by Takhtfooladi et al. $2015^{(10)}$. Hind limb I/R injury was induced by $2 \mathrm{~h}$. ischemia of infra renal aorta, followed by $6 \mathrm{~h}$. of reperfusion. Rats were divided into the following groups:

Group I: Sham-operated: rats were subjected to mid line laparotomy without vascular intervention and injected by a single dose of $1.0 \mathrm{ml}$ normal saline into the caudal vein

Group II: Untreated hind $\operatorname{limb}$ I/R: were injected by a single dose of $1.0 \mathrm{ml}$ normal saline into the caudal vein one hour before ischemia reperfusion injury for hind limb.

Group III: Lipoxin A4-treated hind limb I/R: were injected by a single dose of LXA4 $10 \mu \mathrm{g} / \mathrm{kg}$ into the caudal vein $1 \mathrm{~h}$ before reperfusion injury for hind $\operatorname{limb}^{(11)}$.

Blood samples collection: At the end of the experiments rats were anaesthetized blood samples were collected by decapitation and distributed in dry sterile untreated centrifuge tubes. The blood was allowed to clot at room temperature. Tubes were centrifuged at $2000 \mathrm{rpm}$ for 10 minutes, serum was separated and stored at $70^{\circ} \mathrm{C}$ until the time of analysis and kept in clean storage aliquots.

Tissue homogenates: Left testes were carefully dissected, weighed and divided into 2 parts; the first one was homogenized in volumes of ice-cold Tris- $\mathrm{HCl}$ buffer (50 $\mathrm{mM}, \mathrm{pH} 7.4$ ), homogenization (homogenizer: IKA Ultra-Turrax t 25 Basic, Germany) was carried out for 2 minutes at 13,000 rpm. All procedures were performed at $4^{\circ} \mathrm{C}$. The supernatants were frozen at $-80 \mathrm{C}$ until analysis of different biochemical markers. The tissue protein concentrations were determined by the Lowery method ${ }^{(12)}$. The second part was stored at $-80^{\circ} \mathrm{C}$ till used for gene expression analysis. The right testes was preserved in $4 \%$ buffered paraformaldehyde for histopathological and immunohistochemical examination

\section{Biochemical assays:}

Testicular malondialdehyde (MDA): testicular lipid peroxidation (MDA) was assayed by measuring the thiobarbituric acid reactive substance by colorimetric $\operatorname{method}^{(13)}$.

Testicular catalase activity: Catalase activity was determined as described by Sözmen et al., $2001^{(14)}$

Testicular total nitrite/nitrate: by colorimetric method as described by Miranda et al., 2001 ${ }^{(15)}$.

Testicular tumor necrosis factor alpha (TNF- $\alpha$ ): by commercial sandwich enzyme linked immunosorbent assay (ELISA) $\mathrm{kit}^{(16)}$

Testicular HMGB-1levelsby ELISA kit (Catalog\#YHB1553Hu; Shanghai YH Biosearch Laboratory, Shanghai, China) according to manufacturers' protocol

Testicular caspase-3 activity: The assay was performed according to Slee et al., ${ }^{(17)}$. Caspase-3 activity was expressed as $\mathrm{U} / \mathrm{mg}$ protein.

Serum free testosterone levels: by commercial ELISA kit according to Morely et al. ${ }^{(18)}$

Quantitative measurement of HMGB1 mRNA expression in testicular tissues by quantitative real-time reverse transcription PCR (RT-PCR):

According to the manufacturer's instructions, total RNA was extracted from testicular tissue samples by R Neasy Mini Kit (Roche Diagnostics, GmbH, Mannheim, Germany). The Super-Script II (Invitrogen) was used to reverse-transcribe the RNA to cDNA and the target genes were amplified using Power SYBR Green PCR Master Mix reagent (Applied Biosystems). The primer 
sequences for HMGB- 1 and $\beta$-actin used in the study were as follows:

HMGB-1; forward:

5'-TGATTAATGAATGAGTTCGGGC-3'; reverse: 5'-TGCTCAGGAAACTTGACTGTTT$3^{\prime}$ (according to gene bank accession No: NM_002128.4). $\quad \beta$-actin; forward: 5'CCATTGAACACGGCATTG- 3'; reverse: 5'- GAAGGAAGGCTGGAAGAG- 3' (according to gene bank accession No: NM_001101.3). The amplification was performed in real-time PCR system (Applied Biosystems), and PCR cycles were used as follows: an initial denaturation at $94{ }^{\circ} \mathrm{C}$ for 5 min, 27 cycles of denaturation at $94{ }^{\circ} \mathrm{C}$ for $30 \mathrm{~s}$, annealing at $59{ }^{\circ} \mathrm{C}$ for $30 \mathrm{~s}$, and extension at $72{ }^{\circ} \mathrm{C}$ for 10 minutes. The determination of the relative levels of gene expression was performed using the cycle threshold $(\Delta \Delta \mathrm{Ct})$ method and normalized to the $\beta$-actin gene, which was not altered by the experimental conditions ${ }^{(19)}$.

Immunohistochemical determination of caspase-3 activity: by incubation of sections of right testes with monoclonal antibodies against caspase- 3 according to the method described by (Kim et al. 2007) ${ }^{(20}$ ${ }^{\prime}$ Results were scored semi-quantitatively as each section was carefully examined under high power of light microscope for nuclear immunostaining (brown colored) and categorized according to the percentage ratio of immunostained nuclei to total nuclei as follows:

Score 1: No nuclear staining (negative).

Score 2:1-9\% of cells positive for caspase-3.

Score $3:>10 \%$ of cells positive for caspase- 3 .

\section{Histopathological examination:}

Sections of right testes were fixed in bouin's fixation for 6 hours, then washed and stored in $50 \%$ ethyl alcohol until processing and embedded in paraffin wax, then $4 \mu \mathrm{m}$ thickness serial sections were cut and stained by hematoxylin and eosin (H\&E) following standard techniques.

\section{Statistical analysis:}

All values were expressed as mean $\pm \mathrm{SD}$. Data were statistically analyzed using oneway ANOVA for multiple group comparisons, followed by Scheffe (F) test for comparison between individual groups. Significance was set at $(\mathrm{P} \leq 0.05)$. Pearson correlation coefficient was done using SPSS computer program version 15.

\section{RESULTS}

Two hours clamping to infra-renal aorta followed by 6 hours reperfusion (group II) produced significant increase in testicular MDA, nitrite/nitrate (figures 1 and 2), TNF$\alpha$, caspase-3 activity, testicular level of HMGB-1 and relative mRNA expression of HMGB-1 as shown in (table 1) with significant decrease of testicular catalase activity (figure 3) and serum free testosterone (table 1) when compared to group I $(\mathrm{P} \leq 0.05)$.

Interestingly, the LXA4 pretreated I/R group (group III) show statistically significant decrease of testicular MDA, nitrite/nitrate (figures 1 and 2).TNF- $\alpha$, caspase-3 activity, testicular level of HMGB-1 and relative expression of HGMB1 (table 1) with significant increase of testicular catalase activity (figure 3) and serum free testosterone(table 1) when compared to group II $(\mathrm{P} \leq 0.05)$..

From table (2): There was significant negative correlation between serum free testosterone level and either HMGB1testicular level and its relative mRNA expression, testicular MDA, nitrite/nitrate, TNF- $\alpha$ or caspase- 3 activity and significant positive correlation with catalase activity $(\mathrm{P}<0.05)$ both in group II and group III.

Immunohistochemistry results revealed that 2 hours clamping to infra-renal aorta followed by 6 hours reperfusion (group II), induced more than $10 \%$ of apoptotic cells 
positive for caspase-3 when compared to the sham-operated group(group I) as shown in Fig. 4 (A and B). However, LXA4 pretreated $\mathrm{I} / \mathrm{R}$ group (group III) showed significant reduction in number of apoptotic cells positive for caspase-3 to less than $10 \%$ (score-2) as shown in fig. (4C).

\section{Histopathological results:}

Sham-operated group (group I): showed normal testicular architecture as regard basement membrane of seminephrous tubules, basal spermatogonia and different stages of spermatogenesis up to mature sperms in the lumen of the tubules and normal population of sertoli cells. However, there are mildly congested interstitial blood vessels (Fig.5A).Untreated hind limb I/R group (group II): animals showed severe congestion and edema, thick basement membrane loss of cohesion of spermatogenic cells with sequestration of spermatocytes and hyalinization of sequestrated cells in the lumen of the tubules (Fig. 5B). LXA4-pretreated hind limb I/R group (group III): showed mild congestion with minimal edema, mild thickening of basement membrane and mild loss of cohesion of spermatogenic cells but no sequestration or hyalinization (Fig. 5C).

Table (1): Testicular levels of TNF- $\alpha$, caspase-3, HMGB-1 and its testicular mRNA relative expression and serum free testosterone among studied group

\begin{tabular}{|l|c|c|c|}
\hline \multicolumn{1}{|c|}{ Parameters } & $\begin{array}{c}\text { GI } \\
\text { Sham-operated group } \\
(\mathrm{n}=15)\end{array}$ & $\begin{array}{c}\text { GII } \\
\text { untreated hind } \\
\text { limb I/R } \\
(\mathrm{n}=15)\end{array}$ & $\begin{array}{c}\text { GIII } \\
\text { Lipoxin A4treated } \\
\text { group } \\
(\mathrm{n}=15)\end{array}$ \\
\hline Testicular TNF- $\alpha$ (pg/mg protein) & $28.62 \pm 5.31$ & $60.08 \pm 6.22^{\mathrm{a}}$ & $33.82 \pm 5.15^{\mathrm{b}}$ \\
\hline Testicular caspase-3 activity (U/mg protein) & $0.045 \pm 0.003$ & $0.059 \pm 0.002^{\mathrm{a}}$ & $0.048 \pm 0.003^{\mathrm{b}}$ \\
\hline $\begin{array}{l}\text { Testicular HMGB-1 mRNA relative } \\
\text { expression }\end{array}$ & $0.56 \pm 0.368$ & $1.58 \pm 0.499^{\mathrm{a}}$ & $0.71 \pm 0.12^{\mathrm{b}}$ \\
\hline TesticularHMGB-1 (pg/mg protein) & $5.32 \pm 1.82$ & $14.53 \pm 1.54^{\mathrm{a}}$ & $5.92 \pm 1.67^{\mathrm{b}}$ \\
\hline Serum free testosterone (ng/ml) & $5.42 \pm 0.45$ & $2.67 \pm 0.33^{\mathrm{a}}$ & $5.02 \pm 0.46^{\mathrm{b}}$ \\
\hline
\end{tabular}

TNF- $\alpha$ : tumor necrosis factor alpha, HMGB-1: high mobility group box-1 protein. $n=$ number of rats Data are given as mean $\pm \mathrm{SD} .{ }^{a}: \mathrm{P}<0.05$ group II vs. group I and ${ }^{\mathrm{b}} \mathrm{P}<0.05$ group III vs. group II.

Table (2): Correlation between serum free testosterone and other studied parameters in group II \& group III

\begin{tabular}{|l|c|c|c|c|}
\hline \multirow{2}{*}{ Parameters } & \multicolumn{3}{c|}{\begin{tabular}{c} 
Serum free testosterone (ng/ml) \\
\cline { 2 - 5 }
\end{tabular}} & \multicolumn{2}{|c|}{$\begin{array}{c}\text { Group II } \\
(\mathrm{n}=15)\end{array}$} & \multicolumn{2}{c|}{$\begin{array}{c}\text { Group III } \\
(\mathrm{n}=15)\end{array}$} \\
\cline { 2 - 5 } & r-value & p-value & r-value & p-value \\
\hline Testicular MDA (nmol/mg protein) & -0.731 & $0.016^{*}$ & -0.849 & $0.002^{*}$ \\
\hline Testicular catalase activity $(\mathrm{U} / \mathrm{mg}$ protein) & 0.685 & $0.029^{*}$ & 0.689 & $0.028^{*}$ \\
\hline Testicular nitrite /nitrate $(\mu \mathrm{mol} / \mathrm{mg}$ protein) & -0.825 & $0.003^{*}$ & -0.634 & $0.049^{*}$ \\
\hline Testicular TNF- $\alpha$ (pg/mg protein) & -0.679 & $0.031^{*}$ & -0.636 & $0.048^{*}$ \\
\hline Testicular caspase-3 activity (U/mg protein) & -0.822 & $0.004^{*}$ & -0.710 & $0.019^{*}$ \\
\hline Testicular HMGB-1 mRNA relative expression & -0.678 & $0.032^{*}$ & -0.699 & $0.039^{*}$ \\
\hline testicularHMGB-1 (pg/mg protein) & -0.710 & $0.021^{*}$ & -0.679 & $0.031^{*}$ \\
\hline
\end{tabular}

Data are given as mean \pm SD. * Statistically significant at $\mathrm{p}<0.05$. 


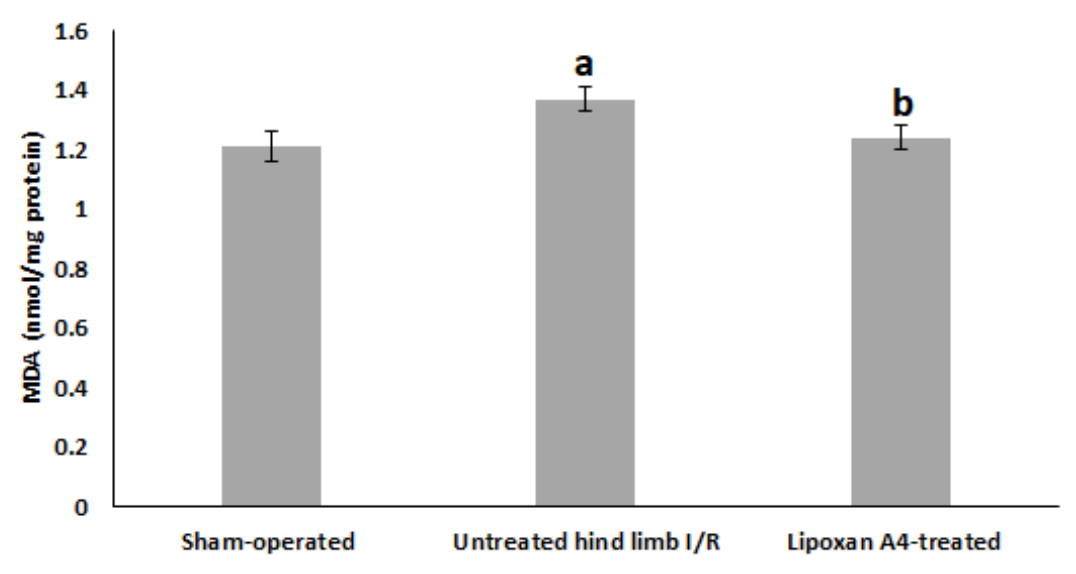

Figure (1): Testicular MDA levels among studied groups. Data are given as mean $\pm \mathrm{SD}{ }^{\mathrm{a}}: \mathrm{P}<0.05$ group II versus group I and ${ }^{\mathrm{b}} \mathrm{P}<0.05$ groupIII versus group II.

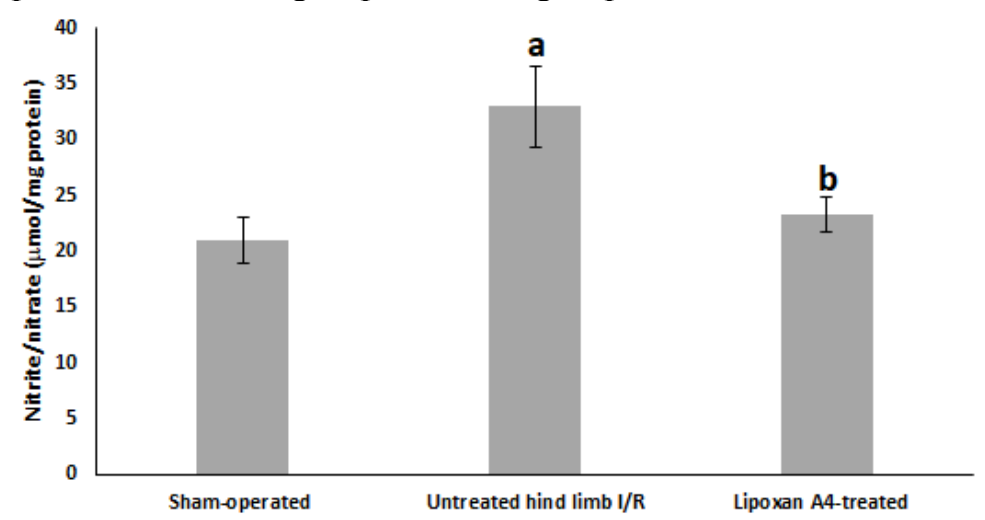

Figure (2):Testicular nitrite/nitrate levels among studied groups. Data are given as mean $\pm \mathrm{SD} .{ }^{a}: \mathrm{P}<$ 0.05 group II versus group I and ${ }^{\mathrm{b}}: \mathrm{P}<0.05$ group III versus group II.

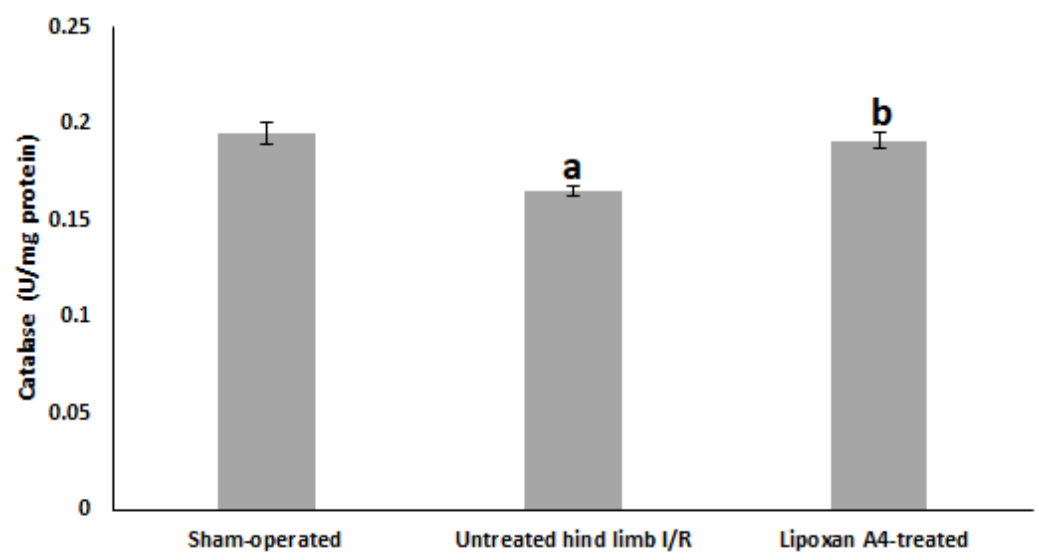

Figure (3): Testicular catalase activity among studied groups. Data are given as mean $\pm \mathrm{SD}^{\mathrm{a}}$ : $\mathrm{P}<0.05$ group IIversus group I and ${ }^{\mathrm{b}} \mathrm{P}<0.05$ group III versus group II. 


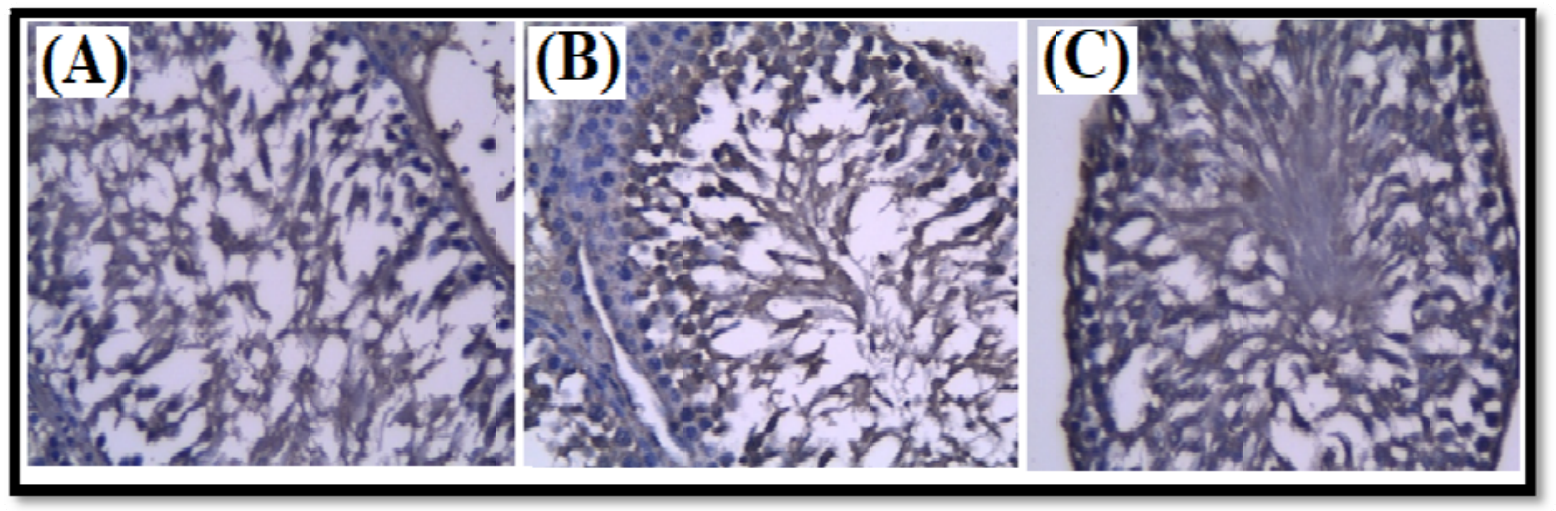

Figure (4): (A) Sham-operated group (group I), immunoreactivity of testicular section showing negative for caspase-3 (score-1: no apoptotic cells). (B) $>10 \%$ of cells positive for caspase-3 (Score3 ), as showed by immunoreactivity of testicular section of animals subjected to hind limb I/R (group II). (C) $<10 \%$ of cells positive for caspase- 3 (score-2) as showed by immunoreactivity of testicular section of LPXA4- pretreated hind limb I/R group (group III), Pap stain x400.

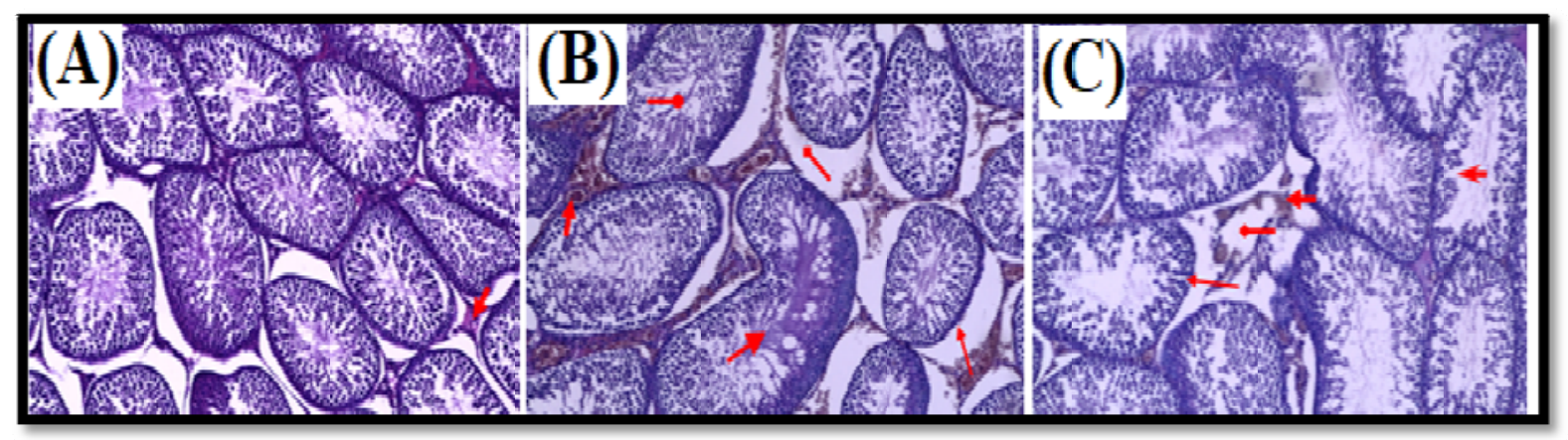

Figure (5): (A) Normal testicular architecture and slightly congested vessels of testicular section of (group I).(B) Red arrows point tosevere congestion, severe edema, thick basement membrane (BM) with focal loss of cohesions ofspermatogenic cells, sequestrated spermatogenic cells in the lumen and hyalinization (group II).(C) Red arrows point to mild congestion of interstitial vessels, minimal edema, mild thickening of (BM) and mild loss of cohesions of spermatogenic cells (group III). All figures (H\&E x 125).

\section{DISCUSSION:}

This study revealed that hind limb $\mathrm{I} / \mathrm{R}$ results in impairment of testicular function with accompanied oxidative stress, inflammatory reactions and apoptosis. Significant increase in MDA in untreated hind limb I/R group could be explained as prolonged ischemia leads to oxidation of ATP with production of hypoxanthine as a breakdown product. This oxidation results in conversion of molecular oxygen into highly reactive superoxide and hydroxyl radicals. On reperfusion, oxygen required for change of hypoxanthine to uric acid becomes available resulting in generation of large number of free radicals which results in lipid peroxidation in the cell and mitochondrial membranes leading to disturbance of cellular integrity $^{(21)}$. Sperms are highly sensitive to lipid peroxidation because of high content of polyunsaturated fatty acids in their plasma membranes ${ }^{(22)}$. Oxidative damage occurs when the endogenous stores of antioxidant enzymes become unable to handle with the excessive number of reactive oxygen species generated after $\mathrm{I} / \mathrm{R}$ resulting in pathological damage in sperm membranes, proteins and $\mathrm{DNA}^{(23)}$.

Ischemic lesion aggregates conversion of NO (nitric oxide) to nitrite by 
deoxyhemoglobin and deoxymyoglobin components of mitochondrial electron transport chain $^{(24)}$ as well as, by enzymatic reduction by xanthine oxidoreductase ${ }^{(25)}$. Many cells such as endothelial cells, phagocytic cells and sertoli cells are capable of NO release, where NO can easily react with superoxide ion to produce peroxynitrite which can react with enzymes thiol esters and glutathione. These nitrating agents may have strong inhibitory potential on the spermatozoa mitochondrial functions also have strong vasodilator effect ${ }^{(26)}$. NO especially via inducible nitric oxide synthase (iNOS), can activate many inducible intracellular pathways like NF- $\kappa$ Bwhich leads to cellular apoptosis ${ }^{(27)}$. The increase in cytokine production like TNF- $\alpha$, IL- 1 and IL-6 during inflammatory and hypoxic condition may be responsible for the increased NO production ${ }^{(28)}$.

The blood cells especially neutrophils and macrophages recruited during reperfusion resulting in release a host of oxygen free radicals and inflammatory cytokines that induce testicular tissue damage and apoptosis which is crucially dependent on the activation of certain intracellular proteases, called caspases, typically activated in a cascade fashion ${ }^{(29)}$ .Hyman and Yuan $(2012)^{(30)}$ stated that, the increase in caspase-3 during ischemia is responsible for tissue damage and selective caspase-3 inhibitor gives protection of tissues against ischemic insult. HMGB-1 is mainly located in the nuclei of most cells. HMGB-1 can also be released from the nucleus into the cytoplasm and extracellular matrix by two processes, either passive release from damaged and necrotic cells or by active secretion if the cells are stimulated by inflammatory mediators or by immune cells $^{(5)}$. This can explain significant increase in HMGB-1 serum levels and tissue expression in hind limb ischemia reperfusion group, where excessive release of inflammatory cytokines as TNF- $\alpha$ in addition to excessive peroxynitrite formation as a result of reaction between NO and ROS. This explanation is supported by previous study that described excessive release of HMGB-1 by hypoxic tissue in I/R injury of the heart secondary to the stimulatory effect of peroxynitrite on HMGB-1 secretion ${ }^{(31)}$. In addition extracellular HMGB-1 acts as a proinflammatory cytokine that mediates the inflammatory response to injury via activation of cytokines and some receptors, including toll-like receptors 4 (TLR-4) as well as induction of NF- $\kappa \mathrm{B}$ signaling pathway $^{(4)}$. The significant decrease in free serum testosterone and its negative correlation with inflammatory, oxidative stress apoptotic markers after ischemia reperfusion injury can be explained by loss of capacity of Leydig cells for steroidogenesis, as they suffer from apoptosis as well as oxidative damage during reperfusion leading to lipid peroxidation, protein denaturation and DNA damage $^{(32)}$.

Lipoxin A4 treated group showed significant reversal of all measured parameters in comparison to the untreated $\mathrm{I} / \mathrm{R}$ group. The antioxidant effect of LXA4 is evidenced by decreased MDA and increased catalase activity, this antioxidant effect can be explained by its ability for induction of hemeoxygenase-1 enzyme which is an important member of cellular defense mechanism against oxidative stress and peroxisome proliferator activated receptor- $\gamma$ (PPAR $\gamma$ ) that has anti-inflam-matory and antioxidant effects, also LXA4 enhances the production of nuclear factor E2-related factor 2 (Nrf2) and improves its nuclear translocation. $\mathrm{Nrf} 2$ is a potent endogenous intracellular defense against cytotoxic effect of oxidative stress ${ }^{(33)}$. The current study reported the ability of LXA4 to decrease nitrite/nitrate ratio. Effect of Lipoxin A4 on nitric oxide production is controversial, previous study reported that LXA4 increased the production of $\mathrm{NO}$ from both endothelial nitric oxide synthase (eNOS) and $\mathrm{iNOS}^{(34)}$ while, another study reported decreased NO 
production by LXA4 due to its ability to suppress interleukin $-1 \quad \alpha$ (IL-1 $\alpha)$ induced production of $\mathrm{NO}^{(35)}$. The anti-inflammatory effect of Lipoxin A4 may be mediated through its inhibitory effect on expression of nuclear factor kappa-light-chain-enhancer of activated $\mathrm{B}$ cells $(\mathrm{NF}-\kappa \mathrm{B})^{(6)}$, which is primary regulator of gene expression for many inflammatory cytokines and is activated during $\mathrm{I} / \mathrm{R}$ injury. LXA4 also increases expression of the protective cytokine interleukin 10(IL-10) which has inhibitory effects on TNF- $\alpha$, interleukin 1(IL -1) and interleukin 6(IL-6) ${ }^{(36)}$.

Previous studies have shown that the secretory mechanism of HMGB1 is mediated by the regulation of acetylation of $\mathrm{HMGB}^{(37)}$. LXA4 inhibits the acetylation and expression of HMGB1 upon activation by lipopolysaccharide (LPS), also it has been reported that LXA4 affected the levels of TLR4 and receptor for advanced glycation end products (RAGE) ${ }^{(38)}$ These reduce the interaction between HMGB1 and RAGE that is involved in the process of inflammation via activation of extracellular signal-regulated kinases (ERK1/2) and NF$\kappa \mathrm{B}$ signaling pathways. More interestingly LXA4 treatment directly reduced the phosphorylation of (ERK1/2) and nuclear NF- $\kappa$ B pathway ${ }^{(39)}$. The anti-apoptotic effect of LXA4 could be explained by its ability to increase expression of B-cell lymphoma leukemia gene 2 (Bcl-2), an anti-apoptotic protein that prevents mitochondrial depolarization and the molecular chaperone heat shock protein 70 (HSP-70) in $\mathrm{I} / \mathrm{R}$ models $^{(11)}$. It inhibits the apoptosis induced by LPS via activation of the PI3K/Akt and ERK/Nrf-2 pathways; in addition, LXA4 inhibited the release of mitochondrial mediators of apoptosis and the activation of caspases $^{(40)}$. Also, the anti-apoptotic effect of LXA4 is enhanced by its rapid and efficient antioxidant effect $^{(7)}$ accordingly, serum free testosterone showed significant increases in LXA4 treated group via its anti- inflammatory, antioxidant, anti-apoptotic and its ability to increase NO production

\section{Conclusion:}

LXA4 treatment can be used as a novel therapeutic approach in $\mathrm{I} / \mathrm{R}$ of testis with its evident protective effect to ameliorate the injurious effect of hind limb $\mathrm{I} / \mathrm{R}$ and to decrease rate of surgical resection of the ischemic testis. This improvement in LXA4 -treated I/R may be explained its antioxidant, anti-inflammatory with its ability to reduce expression of HMGB1, antiapoptotic effects and its ability to increase NO production. However, its use requires additional basic research in different species.

\section{Acknowledgment:}

We would like to acknowledge Prof. Dr. Karima Eldesoky, professor of pathology, for her help in the immunohistochemical and histopathological results of this work.

Funding: No grants or funding have been received for this study.

Conflict of interest: the authors declare that they have no conflict of interests.

\section{REFERENCES:}

1. Blecha MJ. Critical limb ischemia. Surg Clin North Am. 2013; 93 (4):789-812.

2. Granger DN, Kvietys PR. Reperfusion injury and reactive oxygen species: The evolution of a concept. Redox Biol. 2015; 6: 524-51.

3. Wang L, Chen F, Pan Y, Lin L, Xiong X. Effects of FTY720 on Lung Injury Induced by Hindlimb Ischemia Reperfusion in Rats. Mediators Inflamm. 2017; 2017:5301312.

4. Magna M, Pisetsky DS. The role of HMGB1 in the pathogenesis of inflammatory and autoimmune diseases. Mol Med. 2014; 24; 20: 138-46.

5. Kang R, Chen R, Zhang Q, Hou W, Wu S, et al. HMGB1 in health and disease. Mol Aspects Med. 2014; 40:1-116. 
6. Bonnans C, Gras D, Chavis C, Mainprice B, VachierI, et al. Synthesis and antiinflammatory effect of lipoxins in human airway epithelial cells. Biomed Pharmacother. 2007; 61(5): 261-7.

7. Ribeiro LR, Loures FV, de Araújo EF, Feriotti C, Costa TA, et al. Lipoxin Inhibits Fungal Uptake by Macrophages and Reduces the Severity of Acute Pulmonary Infection Caused by Paracoccidioidesbrasiliensis. Mediators Inflamm. 2015; 2015: 852574.

8. Kephart WC, Mumford PW, Mao X, Romero MA, Hyatt HW, et al . The 1-Week and 8-Month Effects of a Ketogenic Diet or Ketone Salt Supplemen-tation on MultiOrgan Markers of Oxidative Stress and Mitochondrial Function in Rats. (Nutrients. 2017 Sep; 9 (9): 1019.

9. Tietz NW. Clinical guide to laboratory tests. W B Saunders, Co., Philadelphia; 3rd edition: pp. 1995; 578- 580.

10. Takhtfooladi MA, Asghari A, Takhtfooladi HA, Shabani S. The protective role of curcumin on testicular tissue after hind limb ischemia reperfusion in rats. Int. Urol. Nephrol. 2015; 47(10):1605-10.

11. Haiyang Zong, Xinghui Li, Haodong Lin, Chunlin Hou, and Fenfen Ma. Lipoxin A4 pretreatment mitigates skeletal muscle ischemia-reperfusion injury in rats. Am $\mathrm{J}$ Transl Res. 2017; 9(3): 1139-1150.

12. Lowry $\mathrm{OH}$, Rosebrough $\mathrm{NJ}$, Farr $\mathrm{AL}$, Randall RJ. Protein measurement with the Folin phenol reagent. J Biol Chem. 1951; 193 (1): 265- 275.

13. Ohkawa H, Ohishi N, Yagi K. Assay for lipid peroxides in animal tissues by thiobarbituric acid reaction. Anal Biochem. 1979; 95 (2): 351-8.

14. Sözmen EY, Sözmen B, Delen Y, Onat T. Catalase/superoxide dismutase (SOD) and catalase/paraoxonase (PON) ratios may implicate poor glycemic control. Arch Med Res. 2001; 32 (4):283-7.

15. Miranda KM, Espey MG, Wink DA. A rapid, simple spectrophotometric method for simultaneous detection of nitrate and nitrite. Nitric Oxide. 2001; 5 (1):62-71.
16. Brouckaert P, Libertc, Everaerdt B, Takahashi N, Cawels A, et al. Tumer necrosis factor, its receopors and the conection with interluken 2 and interluken 6. Immunobiology.1993;187 (3-5) 317-29

17. Slee E.A, Harte M.T., Kluck R. M., Wolf BB., Casiano C.a., teal. Ordering the cytochrome C-initiated caspasescascade: Hierarchical activation of caspases $-2,-3,-6$, $-7,-8$, and -10 in caspases -9 dependant manner. J. cell. Biol 1999.,14492): 281-92

18. Morely J.E., Patrick P., and Perry H.m. $3^{\text {rd }}$ : Evaluation of asssyavalible to measure free testestrone. Metabolism .2002: 51(5):554-9

19. Qiu QM, Li ZW, Tang LM, Sun Q, Lu $Z Q$,et al. Expression of high mobility group protein $\mathrm{B} 1$ in the lungs of rats with sepsis. World J Emerg Med. 2011; 2 (4): 302-6.

20. Kim SK, Yoon YD, Park YS, Seo JT and Kim JH. Involvement of the Fas-Fas ligand system and active caspase- 3 in abnormal apoptosis in human testes with maturation arrest and Sertoli cell-only syndrome. Fertil Steril.2007; 87 (3): 547-553

21. Kalogeris T, Baines CP, Krenz M, Korthuis RJ. Ischemia/Reperfusion. Compr Physiol. 2016; 7(1):113-170.

22. Rui BR, Shibuya FY, Kawaoku AJT, Losano JDA, Angrimani DSR, et al. Impact of induced levels of specific free radicals and malondialdehyde on chicken semen quality and fertility. Theriogenology.2017; 90:11-19.

23. Kumar N, Singh AK .Reactive oxygen species in seminal plasma as a cause of male infertility. J Gynecol Obstet Hum Reprod. 2018; 47 (10):565-572.

24. Gladwin MT, Grubina R, Doyle MP. The new chemical biology of nitrite reactions with hemoglobin: R-state catalysis, oxidative denitrosylation, and nitrite reductase/anhydrase. Chem. Res. 2009; 42 (1): 157-67.

25. Battelli MG, Polito L, Bolognesi A. Xanthine oxidoreductase in atherosclerosis pathogenesis: not only oxidative stress. Atherosclerosis. 2014; 237 (2):562-7.

26. Ozmerdiven G, Coskun B, Kaygisiz O, Vuruskan BA, Asiltas B, et al. The 
protective effect of L-arginine, tadalafil, and their combination in rat testes after ischemia and reperfusion injury. Can Urol Assoc J. 2017; 11 (1-2): E19-E25.

27. Guo Y, Deng Y, Huang Z, Luo Q, Peng Y, et al. EBP50 induces apoptosis in macrophages by upregulating nitric oxide production to eliminate intracellular Mycobacterium tuberculosis. Sci Rep. 2016; 6:18961.

28. Filho DW, Torres MA, Bordin AL, Crezcynski-Pasa TB, Boveris A. Spermatic cord torsion, reactive oxygen and nitrogen species and ischemic reperfusion injury. Mol Aspects Med. 2004; 25(2): 199-210.

29. Hadi NR, Yusif FG, Yousif M, Jaen KK. Both castration and goserelin acetate ameliorate myocardial ischemia reperfusion injury and apoptosis in male rats. ISRN Pharmacol, 2014; 2014; 1-7.

30. Hyman BT, Yuan J. Apoptotic and nonapoptotic roles of caspases in neuronal physiology \& pathophysiology. Nat Rev Neurosci. 2012; 13(6): 395-406.

31. Andrassy M, Volz HC, Igwe JC, Funke B, Eichberger SN, Kaya Z, et al. Highmobility group box-1 in ischemiareperfusion injury of the heart. Circulation. 2008; 117:3216-322630-

32. Bhardwaj JK1, Kumari P1, Saraf P1, Yadav AS. Antiapoptotic effects of vitamins $\mathrm{C}$ and $\mathrm{E}$ against cypermethrin-induced oxidative stress and spermatogonia germ cell apoptosis. J Biochem Mol Toxicol. 2018; 5: e22174

33. Wu SH1, Wang MJ1, Lü J1, Chen XQ1. Signal transduction involved in lipoxin A4induced protection of tubular epithelial cells against hypoxia/reoxygenation injury. ( Mol Med Rep. 2017; 15 (4):1682-1692
34. Gilroy DW. New insights into the antiinflammatory actions of aspirin induction of nitric oxide through the generation of epilipoxins. MemInst Oswaldo Cruz. 2005; 100 (Suppl. I): 49-54

35. Habouri L1, E1 Mansouri FE2, Ouhaddi Y3, Lussier B4, Pelletier JP5, et al. Deletion of 12/15-lipoxygenase accelerates the development of aging-associated and instabilityinduced osteoarthritis. Osteoarthritis Cartilage. 2017; 25 (10):1719-1728

36. Shi Y1, Pan H, Zhang HZ, Zhao XY, Jin J, et al. Lipoxin A4 mitigates experimental autoimmune myocarditis by regulating inflammatory response, NF- $\mathrm{B}$ and PI3K/Akt signaling pathway in mice. Eur Rev Med Pharmacol Sci. 2017 ;21(8):18501859.

37. Lu B, Antoine DJ, Kwan K, Lundbäck P, Wähämaa $H$, et al. Jak/Stat1 Signaling Promotes Hmgb1 Hyperacetylation and Nuclear Translocation. Proc. Natl. Acad. Sci. USA. 2014; 111:3068-3073

38. Liu X1, Wang X1, Duan X1, Poorun D1, $\mathrm{Xu} \mathrm{J} 1$,et al. Lipoxin A4 and its analog suppress inflammation by modulating HMGB1 translocation and expression in psoriasis. Sci Rep. 2017;7(1):7100

39. Hu F1, Liu XX2, Wang X2, Alashkar M2, Zhang S2, et al.LipoxinA4 inhibits proliferation and inflammatory cytokine/ chemokine production of human epidermal keratinocytes associated with the ERK1/2 and NF- $\mathrm{KB}$ pathways. J Dermatol Sci. 2015; 78 (3):181-8

40. Prieto P, Cuenca J, Traves PG, FernandezVelasco M, et al. Lipoxin A4 impairment of apoptotic signaling in macrophages: implication of the PI3K/Akt and the ERK/Nrf-2 defense pathways. Cell Death Differ. 2010; 17:1179-1188 


\section{Abeer A. Abo Zeid and Noha M Shafik}

التأثير التحليلي للييوكسين أــ على ضرر الخصية الناجم عن إصابة في الأطراف الخلفية بالإسكيمية واعادة ضخ الدم في الفئران

الخلفية: إصابات الساق الخلفية ناتجة عن نقص التروية / ضخ الدم مما يؤدي إلى ضرر الخصية هو ضررطبي

يتطلب التدخل العاجل

الههف من العمل: لدراسة تأثير ليبوكسين أ_ـ على إصابة الخصية عن بعد الناجمة عن نقص تروية أطر افهم الخلفية

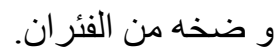

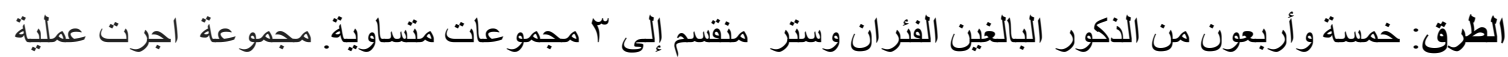

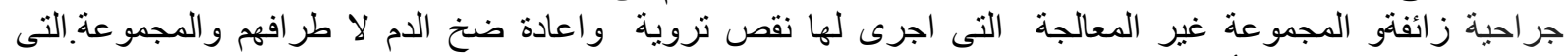

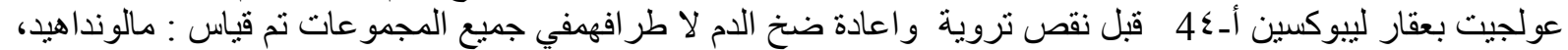

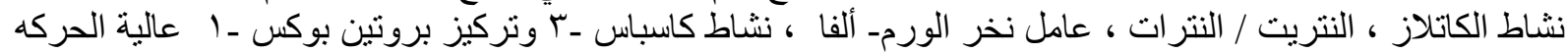

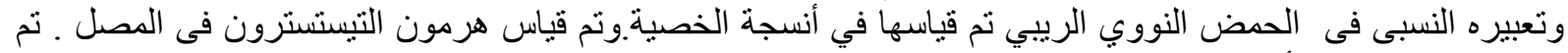

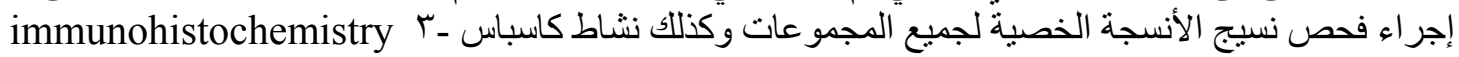

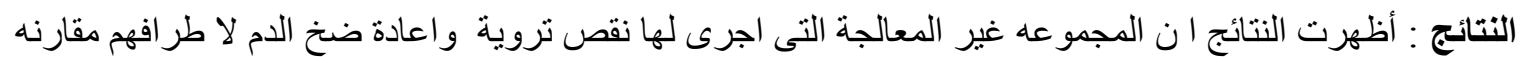

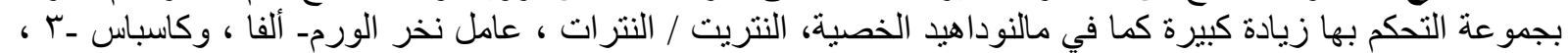

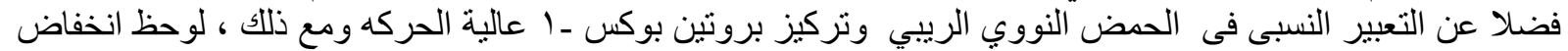

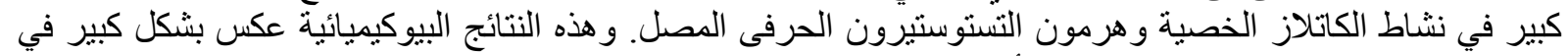

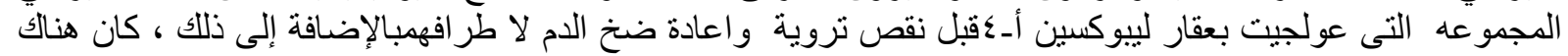

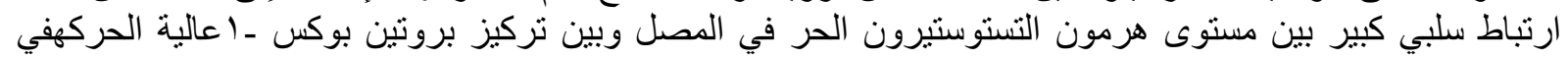

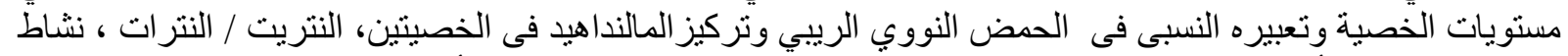

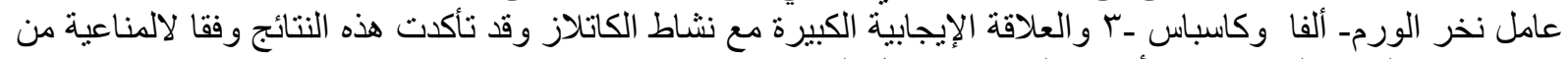

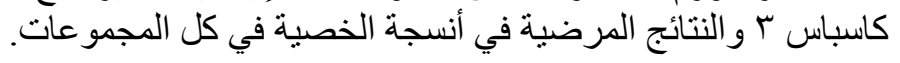

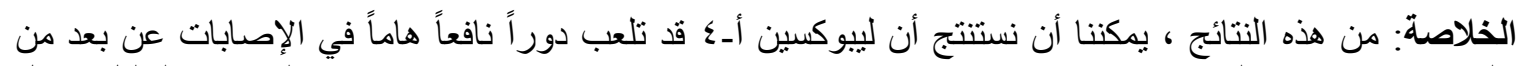

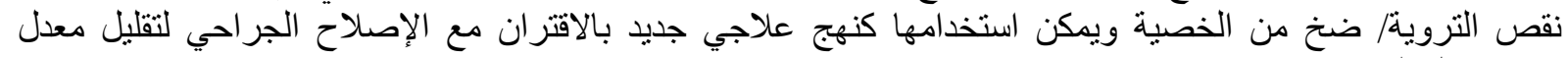

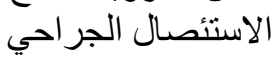

كلمات البحث: ليبوكسين أــ، 1 بروتين بوكس ـ اعالية الحركه: إصابات الساق الخلفية ناتجة عن نقص التروية / ضخ الدم ، الخصية. 